\title{
Virginity sparing surgery for imperforate hymen: report of two cases and review of literature
}

\author{
imperfore himende bekaret koruyucu cerrahi, iki olgu ile literatürün gözden geçirilmesi \\ Osman Temizkan ${ }^{1}$, Suna Kabil Kucur², Sema Ağar ${ }^{1}$, Illay Gözükara², Atıf Akyol ${ }^{1}$, İnci Davas ${ }^{1}$ \\ 'Department of Gynecology and Obstetrics, Sisli Etfal Training and Research Hospital, Istanbul, Turkey \\ ${ }^{2}$ Department of Gynecology and Obstetrics, Nene Hatun Gynecology and Obstetrics Hospital, Erzurum, Turkey
}

\section{Abstract}

Imperforate Hymen (IH), an obstructive congenital anomaly of the female genital tract, is seen in 1 in 2000 female births. Treatment of IH is hymenotomy or hymenectomy. Different types of incisions are mentioned in the literature. We reported two cases of IH with different clinical presentations and described a simple virginity preserving and socially acceptable procedure to protect the virginity of the patient. In cultures and religions where the destruction of the hymen is a social problem in unmarried girls, virginity sparing surgery should be chosen in gynecological practice. Here we described a simple procedure without need for prophylactic antibiotic treatment and foley catheter application to form an intact annular hymen in two cases.

(J Turkish-German Gynecol Assoc 2012; 13: 278-80)

Key words: Virginity, imperforate hymen, genital anomaly, primary amenorrhea, adolescence

Received: 02 April 2012

Accepted: 03 July 2012
Özet

İmperfore himen (iH), kadın genital sisteminin obtrüktif doğumsal anomalisi olup, 2000 kız doğumda bir sıklıkta görülür. Tedavisi himenotomi veya himenektomidir. Literatürde IH tedavisinde farklı tiplerde cerrahi yöntemler tariflenmiştir. Farklı klinik tablolarla başvurmuş iki İH olgusu ile himen bütünlüğünü koruyucu, sosyal olarak kabul edilebilir basit bir yöntem tariflenmiştir. Bekareti korumanın önemli olduğu kültürlerde İH olgularında himen bütünlüğünün korunabildiği prosedürler seçilmelidir. İki İH olgusuyla antibiyotik profilaksisi ve foley kateter kullanmadan intak anüler bir himen oluşturduğumuz basit bir yöntem tanımladık.

(J Turkish-German Gynecol Assoc 2012; 13: 278-80)

Anahtar kelimeler: Bekaret, imperfore himen, genital anomali, primer amenore, adolesan

Geliş Tarihi: 02 Nisan 2012

Kabul Tarihi: 03 Temmuz 2012

\section{Introduction}

Imperforate Hymen (IH), an obstructive congenital anomaly of female genital tract, is seen in 1 in 2000 female births (1). Although it is congenital, in most cases it is diagnosed in adolescence when it prevents passage of blood, causing accumulation of menstrual products in the vagina or uterus. Patients are usually brought to pediatric emergency services with the complaint of cyclic lower abdominal pain, dysuria and, rarely, acute urinary retantion. Treatment is a simple surgical procedure with a few types of incisions on the imperforate hymenal membrane. As it is evidence of virginity, an intact hymen is important in some cultures and religions. Patients and families have fears about loosing virginity after surgical interventions, so the surgeon should choose the technique that provides the best natural annular intact hymenal architecture under those circumstances.

The aim of this case report is to show different presentations of $\mathrm{IH}$ and a simple virginity preserving socially acceptable procedure to provide an annular intact hymen.

We report 2 cases of $\mathrm{IH}$ admitted to Sisli Etfal Training and Research Hospital Emergency Service.

\section{Case Reports}

\section{Case 1}

A 15 year old girl was admitted to the pediatric emergency department with severe abdominal pain for 5 hours. She had a history of vague lower abdominal and back pain for the previous 15 days. On physical examination there was no rebound tenderness but suprapubic and bilateral lower abdominal pain. In the complete blood count, white blood cell: 12.5x109/L, hemoglobin: $13.2 \mathrm{~g} / \mathrm{dL}$, and hematorit level $38.1 \%$. Urinalyses revealed no specific finding. Physical exam revealed a healthy girl with signs of adrenarche and thelarche. On transabdominal ultrasonography, the vagina and uterine cavity were filled with blood suggesting hematometra and hematocolpos. She was referred to our obstetric and gynecology outpatient clinic. On genital exanination, a bulging imperforate hymen was seen. The patient and her family were informed about the situation. The family stated their desire for conservation of virginity. A small central hymenotomy was performed under general anesthesia and about $700 \mathrm{ml}$ of blood was evacuated. The next day she was discharged from the hospital. She had regular mensruation

Address for Correspondence: Suna Kabil Kucur, Department of Gynecology and Obstetrics, Nene Hatun Gynecology and Obstetrics Hospital, Erzurum, Turkey Phone: +905323559047 e.mail: dr.suna@hotmail.com

(C) Copyright 2012 by the Turkish-German Gynecological Education and Research Foundation - Available online at www.jtgga.org doi:10.5152/jtgga.2012.46 
at follow up for 8 months. Now she has an intact annular hymen (Figure 1).

\section{Case 2}

A 13 year old premenarcheal girl presented to the pediatric emergency department with the complaint of urinary retention for 24 hours and constipation for 3 days. She had a history of lower abdominal pain for two months. She had no nausea, vomiting or diarrhea. She was referred to the pediatric urology service with the diagnosis of glob vesicale. In the urology service, after catheterisation of the bladder she was referred to our obstetric and gynecology clinic. On transabdominal ultrasonography, the uterine cavity was filled with blood and a cystic mass of $11 \times 9 \times 13 \mathrm{~cm}$ in diameter (hematocolpos) was detected (Figure 2, 3). On physical examination, she had well developed secondary sexual characteristics with no history of menarche. There was no rebound tenderness but there was suprapubic pain on abdominal examination. Her vital signs were normal. A bluish imperforate hymen was seen on genital examination. All blood and urine laboratory tests, including $\beta$-HCG, were normal. The diagnosis was hematocolpos with hematometra. The hematocolpos was so severe as to cause obstruction of the urethra. The patient and her family were informed about the situation and the procedure. We performed a small cen-

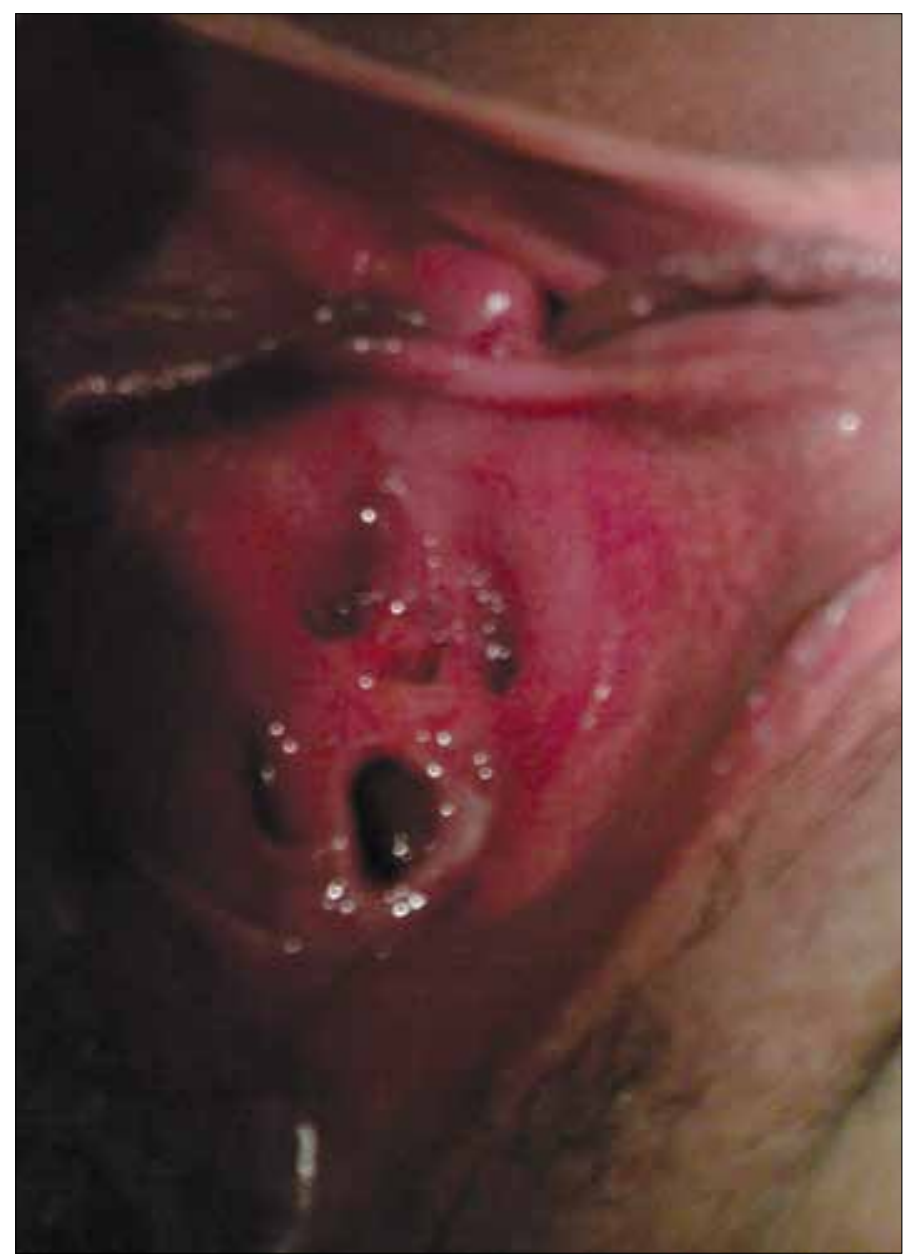

Figure 1. Intact annular hymen after operation tral circular hymenotomy, forming an intact annular hymen . Following drainage of about $1100 \mathrm{~mL}$ of blood, we performed vaginal washing. The patient was discharged on the following day. Follow up of the girl during 6 months was normal with regular menstrual cycles and no restenosis of the hymen.

\section{Discussion}

$\mathrm{IH}$ is not an uncommon entity and diagnosis is easy with thorough history taking and genital examination. IH is usually sporadic, but some familial cases have been reported so far $(2,3)$. Despite the ease of diagnosis with simple inspection of the external genitalia, the detection of $\mathrm{IH}$ can be delayed or missed. Possible complications of delayed diagnosis include endometriosis secondary to retrograde menstruation and ruptured hematosalpynx. As $\mathrm{IH}$ is asymptomatic and until the onset of mentruation it usually remains undiagnosed. However, after menarche when blood begins to accumulate behind the imperforate hymen, hematocolpos, hematometra and hematosalpinx occur, causing cyclic symptoms. Hematocolpos can be so severe to cause obstruction of urethra as in our second case. Urinary retention caused by hematocolpos has been

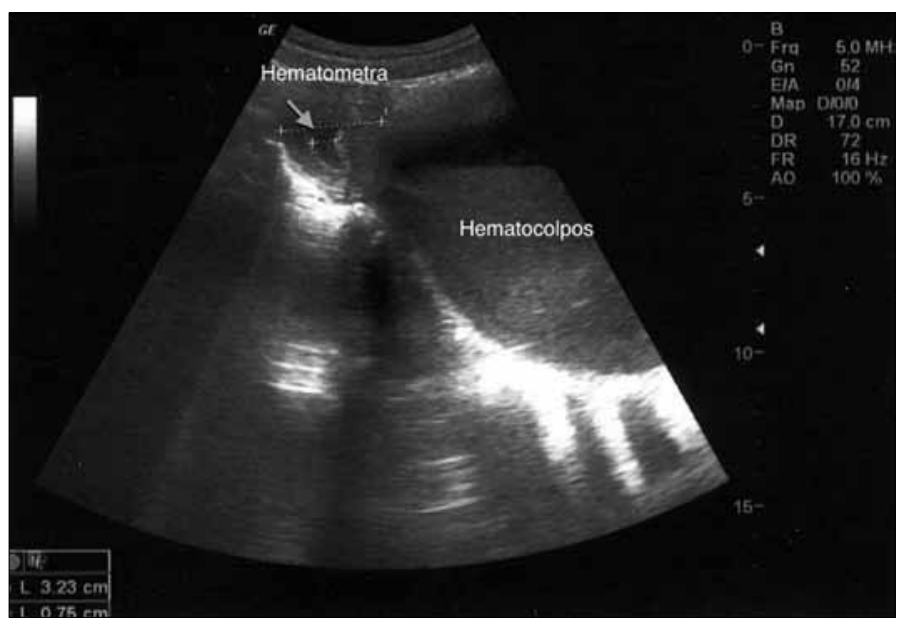

Figure 2. Hematocolpometra

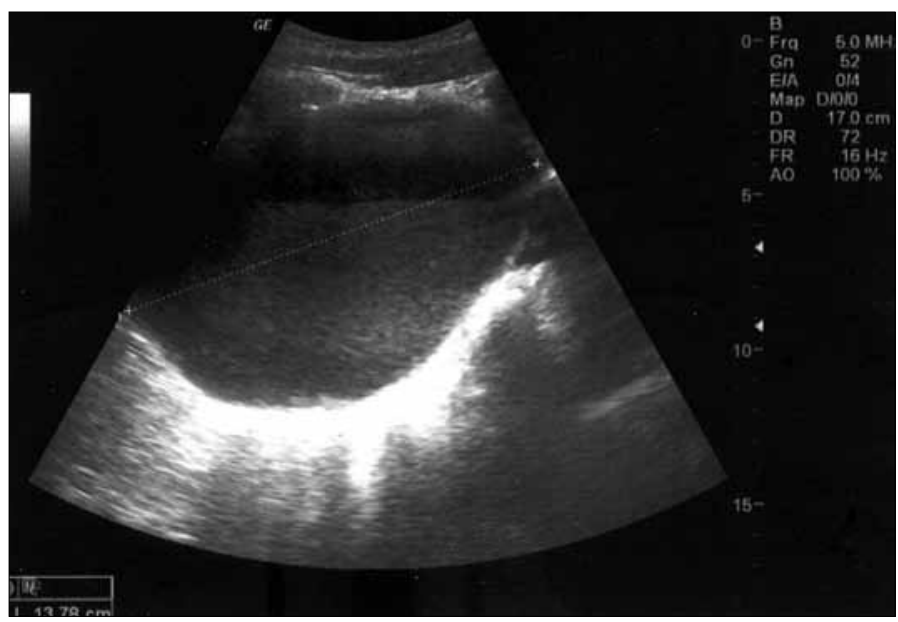

Figure 3 . A cyctic mass of $11 \times 9 \times 13 \mathrm{~cm}$ in diameter (hematocolpos) 
mentioned in a few cases in the literature (4). IH should be kept in mind when evaluating a girl with urinary retention.

It can easily be misdiagnosed as appendicitis or adnexial masses because patients come to the emergency department with nonspecific symptoms such as lower abdominal pain, dysuria, urinary retention, and constipation $(5,6)$. Menstrual history and secondary sexual characteristics should be investigated in such adolescents. The most important clue for diagnosis is absence of menarche. The diagnosis can be confirmed with the detection of a bluish bulging imperfotare hymen on perineal examination. Therefore, careful perineal examination should be performed in premenarchal girls presenting with abdominal pain and obstructive urinary symptoms. The two cases we reported above both had a history of primary amenorrhea despite well developed secondary sexual characteristics.

Treatment of IH is hymenotomy or hymenectomy. Different types of incisions are mentioned in the literature. Some prefer cruciate or vertical incisions, while the others prefer simple central excision of the hymen making an annular-intact hymen using a foley catheter for 2 weeks in order to prevent restenosis $(7,10)$.

In the cases we reported above, we placed a clamp at the center of the imperforate membrane after the patients were positioned in the lithotomy position. Then we excised a $1 \mathrm{~cm}$ central portion with a circular incision around the clamp, forming an annular intact hymenal ring. The vagina was irrigated with saline solution after drainage of the blood. Although general anesthesia is not needed for this simple intervention, we performed the procedure under general anesthesia because of the patients' preference. Patients were discharged from the hospital on the next day after the procedure. We advised patients to clean the vulva with povidone iodine for one week. There was no complication such as bleeding, infection or restenosis in the follow up of patients for 6-8 months.

The techniques mentioned above have similar restenosis risks, so incision type depends on patient's desire or surgeon's preferance. In cultures where the destruction of the hymen is a social problem in unmarried girls, it is important to preserve the annular structure of the hymen in gynecological practice. We prefer the simple central circular excision of the hymen leaving an intact annular hymen as described by Acar et al. (11) However, we did not use a foley catheter after the procedure. There was no restenosis in the follow up of our patients. It is so uncomfortable especially for such young girls having foreign material protruding from the vagina for two weeks. Also there is no need to give prophylactic antibiotic treatment to patients. The procedure is less invasive than other methods described in the literature. and more comfortable for the patients. The result of two cases is not sufficient to provide a conclusion, but studies with large numbers of cases would show the efficacy of the procedure so that it will have wolrdwide acceptance.

\section{Conflict of interest}

No conflict of interest was declared by the authors.

\section{References}

1. Posner JC, Spandorfer PR. Early detection of imperforate hymen prevents morbidity from delays in diagnosis. Pediatrics. 2005; 115: 1008-12. [CrossRef]

2. Bajaj M, Becker M, Jakka SR, Rajalingam UP. Imperforate hymen: a not so benign condition. J Paediatr Child Health. 2006; 42: 745-6. [CrossRef]

3. Erdemoglu E, Kolusarı A, Şahin GH, Kamacı M. Familyal imperfore himen. J Turkish German Gynecol Assoc. 2007; 8: 88-9.

4. Chircop R. A case of retention of urine and haematocolpometra. Eur J Emerg Med. 2003; 10: 244-5. [CrossRef]

5. Nazir Z, Rizvi RM, Qureshi RN, Khan ZS, Khan Z. Congenital vaginal obstructions: varied presentation and outcome. Pediatr Surg Int. 2006; 22: 749-53. [CrossRef]

6. Wang $\mathrm{W}$, Chen MH, Yang W, Hwang DL. Imperforate hymen presenting with chronic constipation and lumbago: report of one case. Acta Paediatr Taiwan. 2004; 45: 340-2.

7. Adali E, Kurdoglu M, Yildizhan R, Kolusari A. An overlooked cause of acute urinary retention in an adolescent girl: a case report. Arch Gynecol Obstet. 2009; 279: 701-3. [CrossRef]

8. Basaran M, Usal D, Aydemir C. Hymen sparing surgery for imperforate hymen: case reports and review of literature. J Pediatr Adolesc Gynecol. 2009; 22: e61-4. [CrossRef]

9. Ali A, Cetin C, Nedim C, Kazim G, Cemalettin A. Treatment of imperforate hymen by application of Foley catheter. Eur J Obstet Gynecol Reprod Biol. 2003; 106: 72-5. [CrossRef]

10. Chelli D, Kehila M, Sfar E, Zouaoui B, Chelli H, Chanoufi B. Imperforate hymen: $\mathrm{Can}$ it be treated without damaging the hymenal structure? Sante. 2008; 18: 83-7.

11. Acar A, Balci O, Karatayli R, Capar M, Colakoglu M. The treatment of 65 women with imperforate hymen by a central incision and application of Foley catheter. BJOG. 2007; 114: 1376-9. [CrossRef] 